Summer 8-1-2019

\title{
Enforcement Mechanisms for International Standards of Judicial Independence: The Role of Government and Private Actors
}

\author{
Rachel Stopchinski \\ Indiana University Maurer School of Law, rstopchi@indiana.edu
}

Follow this and additional works at: https://www.repository.law.indiana.edu/ijgls

Part of the Comparative and Foreign Law Commons, International Law Commons, Law and Economics Commons, and the Rule of Law Commons

\section{Recommended Citation}

Stopchinski, Rachel (2019) "Enforcement Mechanisms for International Standards of Judicial Independence: The Role of Government and Private Actors," Indiana Journal of Global Legal Studies: Vol. 26 : Iss. 2 , Article 7.

Available at: https://www.repository.law.indiana.edu/ijgls/vol26/iss2/7

This Note is brought to you for free and open access by the Law School Journals at Digital Repository @ Maurer Law. It has been accepted for inclusion in Indiana Journal of Global Legal Studies by an authorized editor of Digital Repository @ Maurer Law. For more information, please contactrvaughan@indiana.edu.

\section{$\Psi$}

JEROME HALL LAW LIBRARY

INDIANA UNIVERSITY

Maurer School of Law
Bloomington 


\title{
Enforcement Mechanisms for International Standards of Judicial Independence: The Role of Government and Private Actors
}

\author{
Rachel Stopchinski*
}

\begin{abstract}
In 2017, the prevailing political party in Poland, Law and Justice (Prawo $i$ Sprawiedliwość), proposed a series of radical legislative changes designed to strip the Polish judiciary of its independence. Though the European Union (EU) has extensively investigated this egregious attack on the rule of law, no concrete steps have been taken to impose sanctions on, or otherwise discipline, the Polish government for defying $E U$ ideals. Despite the fundamental importance of judicial independence in maintaining the rule of law, there are presently no widely adopted international standards of judicial independence. Therefore, no guidelines are promulgated for governments to follow, and no well-executed path of action exits to shepherd wayward countries back into compliance. Something must be done. This paper seeks to explore the history behind the current judicial crisis in Poland, the possibility of implementing concrete international standards of judicial independence, and the feasibility of enforcement mechanisms driven by private actors.
\end{abstract}

\footnotetext{
* J.D Candidate, 2019, Indiana University Maurer School of Law-Bloomington; B.A., 2012, University of Michigan-Ann Arbor. I would like to extend my thanks to Professor Charles Geyh for his guidance throughout the researching and writing of this paper.
}

Indiana Journal of Global Legal Studies Vol. 26 \#2 (Spring 2019)

(C) Indiana University Maurer School of Law 


\section{INTRODUCTION}

While judicial independence ${ }^{1}$ is fundamental to effective, democratic governance, ${ }^{2}$ it is not always guaranteed within countries' constitutional framework. ${ }^{3}$ Thus, there have been several movements to formulate and adopt international standards for judicial independence, such as the ABA's Rule of Law Initiative (ROLI) ${ }^{4}$ and the Central Eastern European Law Initiative (CEELI). 5 These movements, though effective in communicating the importance of protecting judicial independence internationally, 6 have not led to a formally adhered to or enforced set of standards for judicial independence.

1. Judicial independence, for the purposes of this paper, will be defined as independence of the judiciary from undue influence from political actors and other branches of government. Essential to this concept is the judiciary's ability to make reasoned judgments based on their interpretation of the law, rather than based on the ideology of the dominant political party. See generally Lydia Brashear Tiede, Judicial Independence: Often Cited, Rarely Understood, 15 J. CONTEMP. LEGAL ISSUES 129 (2006) (exploring the definition of "judicial independence" and emphasizing the importance of "the judiciary's independence from the executive" and the facilitation of "judicial discretion" as an "explicit part of the judicial decision-making process").

2. See Shimon Shetreet, The Normative Cycle of Shaping Judicial Independence in Domestic and International Law: The Mutual Impact of National and International Jurisprudence and Contemporary Practical and Conceptual Challenges, 10 CHI. J. INT'L L. 275, 277 (2009) ("Principles of independence in the judiciary are essential for ensuring the rule of law, protecting human rights, and securing the continued preservation and development of democratic societies.").

3. See Markus B. Zimmer, Judicial Independence in Central and East Europe: The Institutional Context, 14 TULSA J. COMP. \& INT'L L. 53, 58-59 (2006) (discussing the multifaceted elements both in and beyond constitutional language needed to ensure judicial independence).

4. See What We Do, Governance and Justice System Strengthening, AMERICAN BAR ASSOCIATION, https://www.americanbar.org/advocacy/rule_of_law/what-we-do/governancejustice-system-strengthening.html (last visited Feb. 13, 2019) (describing how the ABA ROLI promotes independence in judicial systems through its judicial reform programs).

5. See CEELI INSTITUTe, JUdicial MANUAL ON INDEPENDENCE, IMPARTIALITY AND INTEGRITY OF JUSTICE 5 (2018) http://ceeliinstitute.org/judicial-manual/ (describing CEELI's efforts to assemble "all relevant international standards which establish and clarify the principle of judicial independence in the administration of justice"); see generally Jacques DeLisle, Lex Americana?: United States Legal Assistance, American Legal Models, and Legal Change in the Post-Communist World and Beyond, 10 U. PA. J. INT'L. ECON. L. 179, 188 (1999) (placing the judicial reform efforts of CEELI in the broader context of American international legal initiatives and describing its initiatives in detail).

6. See James R. Sikenat, The American Bar Association and the Rule of Law, 67 SMU L. REV. 745 (2014) (depicting the success of ABA efforts to promote American ideals of the rule of law internationally, especially through CEELI and related efforts); see generally DeLisle, supra note 5 (providing a favorable depiction of CEELI initiatives). 
This lack of enforced standards plays a role in government and economic instability. ${ }^{7}$ Threats to judicial independence, perhaps by political parties attempting to seize control over the rule of law (as will be discussed later), lead to broader economic instability. ${ }^{8}$ International private parties, such as corporations, rely on stable governments to adjudicate their disputes. ${ }^{9}$ So, when judicial independence in a particular country is threatened, the economic health and development suffers as private actors are not apt to invest their business in countries where legislation and court judgments are either unpredictable or increasingly issued against them. ${ }^{10}$

The detrimental effects can be seen in countries such as Poland. In 2017, the Law and Justice (Prawo i Sprawiedliwość, or PiS) party, the dominant party in Poland, proposed a series of legislative changes designed to strip the judiciary of its independence, limit judicial discretion, and place more control over the rule of law in the hands of the executive and legislative branches. ${ }^{11} \mathrm{~A}$ number of these proposals were signed into law by the Polish parliament, while the president vetoed others largely because of mass protest by Polish citizens. ${ }^{12}$ The passed legislation sets the terms of sitting district court judges to a fixed length of four years; the Minister of Justice is afforded the power to appoint and dismiss judges without sufficient review from the National Council of the Judiciary (NCJ), "the constitutional body responsible for safeguarding the independence of the court and judges in Poland."13

7. See generally Emma Phillips, The War on Civil Law? The Common Law as a Proxy for the Global Ambition of Law and Economics, 24 WIS. INT'L L.J. 915, 929 (2007) (explaining that in democratic society, "independent and impartial judiciaries contribute to the equitable and stable balance of power within the government" and vitally important to growth of developing countries); Daniel M. Klerman, Legal Infrastructure, Judicial Independence, and Economic Development, 19 PAC. McGeorge GLOBAL BuS. \& Dev. L.J. 427, 433-34 (2007) (describing the correlation between judicial independence and increases in stock prices and equity value).

8. Phillips, supra note 7, at 929 ("Independent and impartial judiciaries] resolve commercial disputes in a predictable and transparent fashion that encourages fair competition and economic growth.").

9. Id.

10. Id.

11. See Michal Bilewicz, Poland's Ruling Party Tried a Judicial Power Grab-and Then Saw It Backfire. Here's Why., THE WASHINGTON POST (July 31, 2017), https://www.washingtonpost.com/news/monkey-cage/wp/2017/07/31/polands-ruling-partytried-a-judicial-power-grab-and-then-saw-it-backfire-heres-

why/?utm_term=.e2e00db0125d (detailing recent judicial reform measures under the PiS political party).

12. Id.

13. See Poland: Independence of the Judiciary and the Right to Fair Trial at Risk, AMNESTY INT'L (Aug. 10, 2017, 2:41 PM), https://www.amnesty.org/en/latest/news/2017/08/ poland-independence-of-the-judiciary-and-the-right-to-fair-trial-at-risk/ (discussing "the 
These proposals threaten Polish judicial independence in several ways. The new judicial appointment structure wears away at the separation of powers in Poland by placing most decision-making about judicial ideology on an official that is highly susceptible to political influence. ${ }^{14}$ Judges are forced to consider the political ideology of the Minister of Justice when making their judgements out of fear of dismissal. ${ }^{15}$ Therefore, the politically influenced Minister of Justice is afforded nearly unabated control over the shaping of the Polish rule of law. ${ }^{16}$

Time will tell what consequences the threats to Polish judicial independence will have on the health of the Polish government and economy. Governing bodies such as the European Union (EU), however, have begun to threaten to invoke its Article 7 sanctions proceedings (restricting Poland's EU voting rights) if Poland does not change its course for fear of its effects on the larger European community. ${ }^{17}$ Other more informal enforcement mechanisms that private actors enact may prove more effective than these sanctions, particularly those that involve economic incentives or punishment.18 Thus, private actors, rather than governmental bodies, could be more apt to instigate the enforcement of standards of judicial independence. ${ }^{19}$

Using Poland as a case study, this paper seeks to explore effective means of preventing threats to judicial independence and remedying deviations from acceptable standards of judicial independence. Further, the paper will investigate the utilization of private actors' actions as regulators of judicial independence in contrast with sanctions and other

range of measures the Polish government is taking or attempting to take to 'reform' the judiciary in Poland" and the impact on the functions of Polish government). Although this is not to say that the NCJ forfeits all right to veto under the new, passed legislation. The NCJ retains the right to veto dismissal of judges, but the standards are heightened to a two-thirds majority vote. Thus, the veto power remains, but the ability of the NCJ to veto is significantly hindered, leaving most of the power in the hands of the Minister of Justice, as the NCJ must reach a firm consensus to invoke their right to disagree with the Minister of Justice's decisions.

14. Id.

15. Id.

16. Id.

17. See Heather Grabbe \& Stefan Lehne, Defending EU Values in Poland and Hungary, CARNEGIE EUROPE (Sept. 4, 2017), http://carnegieeurope.eu/2017/09/04/ defending-eu-values-in-poland-and-hungary-pub-72988 (detailing action being taken by the EU to curb Polish judicial reform).

18. See Paul B. Stephan, Privatizing International Law, 97 VA. L. REV. 1573, 1589 (2011) (detailing the ways that private actors utilize economic "retaliation, reward, reputational adjustment, and norm internalization" to enforce compliance with international law in conjunction with formal sanctions from state actors).

19. See id. at $\mathbf{1 5 7 4}$. 
methods employed by governmental bodies, such as the European Union. Part I will place the conflict in Poland within a historical context of economic-driven judicial reform and international promulgation of judicial independence. Part II will investigate and determine the efficacy of actions taken by government and private actors to influence the stability of the rule of law and protection of judicial independence in the European Union. Lastly, Part III will propose a framework for an enforcement mechanism for judicial independence standards involving the cooperation of both intergovernmental and private actors.

\section{Poilsh Judicial REFoRM, THE PoSt-Soviet ERA ECONOMIC TRANSITION, AND INTERNATIONAL STANDARDS OF JUDICIAL INDEPENDENCE}

Protections for judicial independence were absent when Poland was under the domain of the Soviet Union. ${ }^{20}$ Poland emerged in its independence from the Soviet Union "devoid of any normative and institutional foundation of an independent judiciary." 21 Since then, there has been significant judicial reform, partly driven by its transition to a market-based economy. ${ }^{22}$ Despite several judicial reform initiatives in central Europe, there are still concerns about threats to judicial independence in Poland. ${ }^{23}$ Thus, there is reason to believe that the adoption of more concrete international standards of judicial independence would increase adherence to EU law and policy by member states.

For many reasons, judicial independence was not feasible within the socialist-style governance present in Soviet-era Poland. Primarily, there was an absence of separation of powers, a weak judicial structure, and an overly powerful and politicized legislative branch that held total responsibility for maintaining constitutionalism. ${ }^{24}$ There was no judicial review process, which neither afforded the judiciary any method of assessing the actions of the executive and legislative branches nor the independence or discretion to adjudicate disputes without undue

20. See Daniel Ryan Koslosky, Toward an Interpretive Model of Judicial Independence: A Case Study of Eastern Europe, 31 PA. J. INT'L. L. 203, 209 (2009).

21. Id.

22. Id. at 215 .

23. See OPEN SOC'Y INST., Judicial Independence in Poland, in MONITORING THE EU ACCESSION PROCESS: JUDICIAL INDEPENDENCE 306, 310 (2001) (discussing ongoing concerns about judicial independence in Poland).

24. See Koslosky, supra note 20, at 210-11; see also Ewa Ietowska, Courts and Tribunals Under the Constitution of Poland, 1997 ST. LOUIS-WARSAW TRANSATLANTIC L.J. 69, 69 -70 (1997) (giving a historical perspective of the Polish Constitution and noting the lack of judicial review of constitutional decision under the 1952 communist constitution). 
political influence.25 Judges were afforded little autonomy and "were required to strictly adhere to standard interpretations of the law[;]" all judicial opinions were vetted by the reigning political party before being rendered. 26

Under this system where the government rendered the judiciary powerless, judicial independence was an impossibility. ${ }^{27}$ The judicial branch was stripped of its legitimacy and served no purpose aside from issuing court judgments in the Communist Party's interests. ${ }^{28}$ All of the hallmarks of a modern, properly functioning judiciary simply were not present, and thus, countries like post-Soviet Poland entered democratic governance without the means to properly ensure judicial independence. ${ }^{29}$ Thus, drastic reforms to the judiciary were needed in the post-Soviet government transition.

Judicial reform in this era can be partly explained by the economic transition from socialist property law to a market-based system of private property. ${ }^{30}$ Private property ownership created a variety of concerns that could be best regulated through a stronger judiciary since "the inadequate protection of property rights leads to lower investment rates and slower economic growth."31 So while the legislature could enact laws to minimize economic disputes, ultimately the judiciary became necessary to ensure the enforcement of enacted legislation without fear that their decisions would bring about negative consequences. ${ }^{32}$ Further, when passed legislation is vague, the judiciary's role in private property regimes is to ensure the rights of property owners are respected. ${ }^{33}$ An effective market-based economy, therefore, often relies on a healthy balance between the legislature's actions and regulation mechanisms by the judiciary who interprets,

25. Koslosky, supra note 20, at 211 ("Judicial independence of course presupposes the presence of judicial review. The independence and objectivity of a judge as an adjudicator of disputes is meaningless if he does not have the power to review [the constitutionality of executive and legislative action].").

26. Id. at 211.

27. Id. at 212 .

28. Id.

29. Id.

30. Id. at 215 .

31. Id.

32. See Lars P. Feld \& Stefan Voigt, Economic Growth and Judicial Independence: Cross-County Evidence Using a New Set of Indicators, 19 EUR. J. POL. ECON. 497, 499 (2003) (discussing the way that judicial independence allows the judiciary to adjudicate disputes between various parties without facing negative consequences).

33. See id. at 497-98 (depicting the way that market economies and rational politicians need judicial independence because it ensures that legislation regarding property rights is actually honored). 
shapes, and enforces the law. ${ }^{34}$

In theory, Poland made great strides to reform its judiciary, but until a new constitution was passed in 1997, Poland continued to function under its 1952 Communist Constitution, which left the judiciary's role limited. ${ }^{35}$ The 1997 Constitution opened a new era of judicial reform and activity, but Poland still struggles to maintain judicial independence today. In a 2001 report regarding the EU accession process and the state of judicial independence in newly acquiesced member states, Poland was described as having "made considerable progress" but still having "significant areas of concern." 36 Among these were concerns that the Minister of Justice, a member of the executive branch, retained "considerable administrative and supervisory authority over the organization and affairs of the judiciary." 37 Further, the report cited concerns over the executive's control of the judicial budget, the amount compensation for judges, and judicial tenure. ${ }^{38}$ These ongoing concerns are at odds with EU law and recommendations for judicial independence.

The European Union has codified standards of judicial independence in a few different conventions and charters, but the majority are framed in terms of the universal human right to due process and a fair trial.39 Primarily, existing EU law on this topic is found in the European Convention for the Protection of Human Rights

34. See generally id. (providing a survey of experts in seventy-one countries showing that judicial independence positively impacts the GDP growth per capita in a sample of fifty-seven countries); Katharina Pistor, Martin Raiser \& Stanislaw Gelfer, Law and Finance in Transition Economies, 8 ECON. TRANSITION 325 (2000) (noting the importance of judicial reform in transition economies and through data analysis arriving at the conclusion that reform centered on "legal effectiveness" has the greatest impact on the health of the economy); Shimon Shetreet, Judicial Independence, Liberty, Democracy and International Economy, in THE CULTURE OF JUDICIAL INDEPENDENCE: RULE OF LAW AND WORLD PEACE 14, 14 (Shimon Shetreet ed., 2004) ("It is generally accepted that judicial independence is a central foundation for democracy, liberty, and orderly economy."); Emma Phillips, supra note 7, at 929 ("[R]obust judiciary is essential to ensure that rules are applied fairly and impartially and that they develop appropriately over time.").

35. See Ewa Letowska, Courts and Tribunals Under the Constitution of Poland, 1997 ST. LOUIS-WARSAW TRANSATI.ANTIC L.J. 69, 69 (1997).

36. OPEN SOC'Y INST., Judicial Independence in Poland, in MONITORING THE EU ACCESSION PROCESS: JUDICIAL INDEPENDENCE 306, 310 (2001).

37. Id. at 313 .

38. Id. at 310-11.

39. See Shimon Shetreet, General Introduction, in THE CULTURE OF JUDICIAL INDEPENDENCE: RULE OF LAW AND WORLD PEACE 6 (Shimon Shetreet ed., 2004) ("International law influences domestic law by virtue of international human rights treaties, which provide for principles of fair procedures and for the right to be tried before an impartial and independent tribunal."). 
and Fundamental Freedoms ${ }^{40}$ and the Charter of Fundamental Rights of the European Union. ${ }^{41}$ The premise of the EU promulgation of judicial independence and the rule of law is to "constrai[n] the State" where the state does not constrain itself and pay "straightforward attention to public officials." 42 The flaw in these codified standards is that though they outline the ideology the European Union hopes to protect, they do not outline actionable ways in which member states can ensure that judicial independence is maintained. ${ }^{43}$ For a country like Poland, the vagueness of the law mandating an independent judiciary may allow for non-compliance while a more specific set of judicial independence standards might not. ${ }^{44}$

Scholars have outlined some of the essential elements of judicial independence as: "(1) fixed tenure that offers protection from arbitrary removal and that is subject only to narrowly tailored provisions allowing discipline or removal of judges for misconduct or incapacity; (2) fixed and adequate compensation; (3) minimum qualifications; and (4) limited civil immunity for judicial decisions." 45 Using these essential elements, several international NGO's have sought to create more concrete frameworks for organizing judicial branches and separation of powers to facilitate higher levels of judicial independence.

One of the foremost organizations is the International Association of Judicial Independence and World Peace which, in 2008, drafted the

40. European Convention for the Protection of Human Rights and Fundamental Freedoms, as amended by Protocol No. 14, art. 6, June 1, 2010, CETS no.194.

41. Charter of Fundamental Rights of the European Union, art. 47, 2000 O.J. (C 364) 20.

42. DANIELA PIANA, European Standards of Judicial Governance, in JUDICIAL accountabilities in New Europe: From Rule of LaW to Quality of JuSTICE 49, 51 (Ralf Rogowski ed., 2010).

43. See European Convention for the Protection of Human Rights and Fundamental Freedoms, supra note 40, at 9 ("[E]veryone is entitled to a fair and public hearing within a reasonable time by an independent and impartial tribunal established by law."); see also Charter of Fundamental Rights of the European Union, supra note 41, at 20 ("Everyone is entitled to a fair and public hearing within a reasonable time by an independent and impartial tribunal previously established by law.").

44. See Dimitry Kochenov \& Laurent Pech, Upholding the Rule of Law in the EU: On the Commission's Pre-Article 7 Procedure' as a Timid Step in the Right Direction 4 (European University Institute Robert Schuman Centre for Advanced Studies Global Governance Programme, EUI Working Paper RSCAS No. 24, 2015), http://cadmus.eui.eu/bitstream/handle/1814/35437/RSCAS_2015_24.pdf?sequence=3 (discussing the difficulty in enforcing provisions in the Treaty on European union which express "open-ended" values).

45. Thomas E. Plank, The Essential Elements of Judicial Independence and the Experience of Pre-Soviet Russia, 5 WM. \& MARY BIIL RTS. J. 1, 5 (1996). 
Mount Scopus International Standards of Judicial Independence. ${ }^{46}$ These standards were drafted to acknowledge the judiciary's role in the "protection of human rights and in the operation of an efficient and fair market economy with a human face in the era of globalization." 47 This thirty-seven-page document comprehensively depicts the building and maintaining of a culture of judicial independence both nationally and internationally. 48 In these standards, the culture of judicial independence is reliant on five factors: (1) "creating institutional structure;" (2) "establishing constitutional infrastructures;" "introducing legislative provisions and constitutional safeguards;" (4) "creating adjudicative arrangements and jurisprudence," and (5) "maintaining ethical traditions and code of judicial conduct." 49 Under this methodology, the standards outline concrete ways in which to guarantee judicial independence, such as vesting the removal of a judge in a judicial tribunal rather than in the executive ${ }^{50}$ and ensuring that adequacy of judicial salaries and pensions are adequate and fixed by law. ${ }^{11}$

The Mount Scopus International Standards of Judicial Independence are highly valued and have been incorporated into other NGO's efforts to promulgate standards of judicial independence, such as the CEELI. CEELI is a part of the American Bar Association's (ABA) broader ROLI and focuses on "protect[ing] fundamental rights and individual liberties [and] promot[ing] transparent incorruptible, accountable governments[.]"52 CEELI's Judicial Manual on Independence, Impartiality, and Integrity of Justice, published in August 2017, provides a thematic compilation referencing over one hundred different international standards and is designed to act as "an easy-to-use reference tool to facilitate day-to-day work of judges[.]" ${ }^{3}$ This manual adopts many of the Mount Scopus International Standards of Judicial Independence's principles as to creating a culture of judicial

46. See generally INT'L ASS'N OF JUDICLAL INDEP. AND WORLD PEACE, MOUNT ScOPUS STANDARDS OF JUDICIAL INDEPENDENCE 1 (2008), https://www.jiwp.org/mt-scopusstandards-2007-curre\#!mt-scopus-standards/c14de.

47. Id. at 2. See also Shetreet, supra note 2, at 276 ("The development of the Mt. Scopus Standards was necessitated by the absence of a modern, thorough revision of standards for both national and in ternational judges.").

48. INT'L ASS'N OF JUDICIAL INDEP. AND WORLD PEACE, supra note 46, at 3.

49. Id.

50. Id. at 4 .

51. Id. at 6.

52. Mission of the CEELI Institute, CEELI INSTITUTE, http://ceeliinstitute.org/who-weare/mission/ (last visited Feb. 13, 2019).

53. CEELI INSTITUTE, supra note 5, at 5 (2017), http://ceeliinstitute.org/wpcontent/uploads/2015/07/NewCoverManualJustice_AUG_17.pdf. 
independence. ${ }^{54}$

Standards for judicial independence provide governments with actionable ways to protect judicial independence. Rather than asserting vague ideology - such as the need to protect the right to a fair trial-the Mount Scopus and CEELI standards focus on ways that governments can better organize themselves. These standards focus on developing government structures with a more robust separation of powers by outlining the roles the executive, legislature, and the judiciary play in maintaining judicial independence. So while the standards may make some broad statements, such as "the judiciary as a whole shall be independent," 55 these statements are paired with concrete objectives, such as "the power to discipline or remove a judge must be vested in an institution independent of the Executive" 56 or "legislation introducing changes to the terms of conditions of judicial services shall not be applied to judges holding office at the time of the passing the legislation unless the changes improve the terms of service and are generally applied."57 By specifically outlining the nature of the relationship between the branches of government needed to facilitate judicial independence, these standards better equip governments with the means to effectively promote judicial independence in their own organizational structure.

Thus, standards focused on more actionable objectives make it abundantly clear what is and is not permitted. Under these models, deviations from standards are more easily identified, and therefore, member countries will be more aware what the European Union would not find acceptable. From a practicality standpoint, there is a benefit to imposing uniformity on countries within an intergovernmental organization like the European Union. While these standards lack flexibility, 58 if the European Union maintains its commitment to advancing the rule of law in central and eastern Europe, adopting more concrete standards such as these would assert their viewpoint on judicial independence. Assuming that a core aspect of good governance is establishing law that provides for predictable outcomes, ${ }^{59}$ establishing

54. Id. at 14.

55. INT'L ASS'N OF JUDICIAL INDEP. AND WORLD PEACE, supra note 46, at 6.

56. Id. at 8.

57. Id. at 11 .

58. These standards are less flexible in the sense that adopting them would prescribe specific judicial branch organization onto member states, whereas more broad standards for judicial independence afford member states more freedom in the structuring of their individual governments.

59. See David Boies, Judicial Independence and the Rule of Law, 22 WASH. U. J.L. \& POL. 57, 57 (2006) (describing how a key aspect of the "rule of law" proves that "the rule applied to a particular case must be reasonably predictable"); see generally Phillips, supra 
more explicit guidelines could encourage countries to remain compliant preemptively rather than pushing the boundaries to discover what is and is not acceptable.

\section{The Efficacy of Intergovernmental and Private Actors in Enforcing International Standards of Judicial Independence}

As evidenced through the case of Poland, both private, economic interests and the needs of intergovernmental organizations like the European Union can drive judicial reform. Despite this oversight, due to the lack of concrete standards of judicial independence, states may still deviate from accepted protections of the independent judiciary. When a state launches threats against judicial independence, private actors may play a more effective role in encouraging compliance than intergovernmental organizations. While the European Union can impose sanctions on non-compliant member states, these sanctions may not prove as convincing or as timely as direct economic consequences by private actors for failure of a country to maintain judicial independence.

\section{The Role of the European Union}

Membership in the European Union is highly valued by member states due to the many benefits conferred from affiliation with a larger organization of states. ${ }^{60}$ The European Union thus has an incentive in ensuring that member states comply with its ideals and maintain certain standards of democracy and fair governance. ${ }^{61}$ The European

note 7, at 928 ("Good governance requires a known set of rules that are enforced, effective mechanisms to ensure the legitimate application of these rules, and an independent third party to resolve disputes in their application").

60. See About the EU: Poland, EUROPEAN UNION, https:/leuropa.eu/europeanunion/about-eu/countries/member-countries/poland_en (last visited Feb. 13, 2019) (describing, for example, Poland's involvement in the EU including how, in 2015, total EU spending in Poland reached $€$ 13.258); see also Remi Adekoya, How the EU Transformed Poland, THE GUARDIAN (May 1, 2014, 11:16 AM), https://www.theguardian.com/ commentisfree/2014/may/01/eu-poland-10-years-economic (illustrating the vast economic and social benefit Poland has received from its participation in the European Union); see generally Phillips, supra note 7, at 927(describing how "much-coveted membership in the European Union" drives judicial reform, especially the maintenance of judicial independence in Poland).

61. See Consolidated Version of the Treaty on European Union Preamble, Dec. 13, 2007, 2012 O.J. (C 326) 1 (stating that the Union is founded on the "principles of liberty, democracy, respect for human rights and fundamental freedoms, and the rule of law" principles which are common to the Member States); id. art. 3 (regarding the EU's commitment to advancing its values, the treaty assets that a member state "[i]n its 
Union has maintained a long-term commitment to the promulgation of judicial independence 62 and holds expectations of judicial independence for its member states. ${ }^{63}$ Inherent in judicial independence is the idea that the public has access to its fair day in court where court judgments are not made on the basis of government and political influence but instead on the judge's own interpretation of the law and facts. ${ }^{64}$ As discussed earlier, EU law mandates that member states must maintain independent judiciaries; so when judicial independence is threatened, this violates both EU ideals and laws, and the European Union must act to bring deviating states back into compliance.

The European Union's primary sanction that it could use against a non-compliant state is Article 7, which is intended to be used when EU member countries commit human rights violations. ${ }^{65}$ Article 7 was first created through the 1999 Treaty of Amsterdam ${ }^{66}$ (as an amendment to the previously adopted Treaty on the European Union), 67 where the European Union sought to address the possibility of human rights violations by countries with histories of corrupt governments and with differing ideologies on democracy and the rule of law. ${ }^{68}$ The European Union could send a formal warning to a non-compliant member by invoking Article 7(1).69 By invoking Article 7(2), the European Union

relations with the wider world, the Union shall uphold and promote its values and interests and contribute to the protection of its citizens").

62. PIANA, supra note 42, at 51 ("The EU holds judicial independence and managerial accountability to be the two fundamental conditions for obtaining membership.").

63. See, e.g., Boies, supra note 59, at 58 ("Judicial independence and judicial supremacy work together in an attempt to guarantee that the rule of law will not be eroded by the political pressures in existence at any particular point in time"); Consolidated Version of the Treaty on European Union Preamble, Dec. 13, 2007, 2012 O.J. (C 326) 1 (The Union is founded on the "principles of liberty, democracy, respect for human rights and fundamental freedoms, and the rule of law" principles which are common to the Member States) (emphasis added).

64. See generally Shetreet, supra note 2, at 276 (describing how international human rights treaties value judicial independence because of its connection to fair court procedure).

65. Ginger Hervey \& Emmet Livingstone, What is Article 7?, Politico (Jan. 13, 2016, 10:55 AM), http://www.politico.eu/article/hungary-eu-news-article-7-vote-poland-rule-oflaw/.

66. Id.

67. Treaty of Amsterdam Amending the Treaty on European Union, the Treaties Establishing the European Communities and Certain Related Acts, Oct. 2, 1997, 1997 O.J. (C 340) 1.

68. Id. art. 1 (adding the text "The Union is founded on the principles of liberty, democracy, respect for human rights and fundamental freedoms, and the rule of law, principles which are common to the Member States" to the amended Treaty on European Union).

69. Consolidated Version of the Treaty on European Union art. 7, Dec. 13, 2007, 2012 O.J. (C 326) 1, 7. 
could restrict the non-compliant state's voting rights, which limits its direct influence on the decision-making of the European Union. ${ }^{70}$

Though this possibility exists, Article 7 is a dormant law that has never been invoked; thus, the feasibility of utilizing this sanctioning method to encourage compliance with judicial independence standards is questionable. ${ }^{71}$ This is because Article 7 is a multi-step process that involves thorough review of the offending country's actions with conditions for sanctions that are hard to satisfy. ${ }^{72}$ Further, the "relatively open-ended nature" of EU provisions regarding the "rule of law" make it difficult for the European Commission to take action against non-compliant member states. ${ }^{73}$ The European Union's focus on threats to the rule of law of a "systemic nature" also creates a situation where typically the member state brought up for Article 7 procedures has substantially deviated from EU ideals. ${ }^{74}$ This focus on retroactively punishing member states for straying too far from the EU rule of law principles permits member states to deviate to a point where returning to compliance is time-consuming and intensive. Therefore, Article 7 procedures are not terribly effective in preventing threats to judicial independence in the first place.

Article 7 sanctions are not the only ways that the European Union could take action against non-compliant member states. For example, the European Union could attach conditions to the aid it provides countries that do not comply with standards of judicial independence. The European Union has a seven-year financial framework that provides funding for the advancement of member states. ${ }^{75}$ States that do not adhere to EU values could receive a lower allocation of funding, while states that adhere closely could receive more financial assistance. ${ }^{76}$ This would be akin to economic punishment and could encourage member states to closely follow EU law and policy. There are some downsides to the European Union, however, if it were to take this approach. The EU budget primarily supports "growth and jobs," especially in underdeveloped and disadvantaged populations, and

70. Id.

71. See Kochenov \& Pech, supra note 44 , at 3.

72. Id.

73. Id. at 4 .

74. Id. at 7 .

75. See Budget, EUROPEAN UNION, https://europa.eu/european-union/topics/budget_en (last visited, Feb. 13, 2019).

76. See Overview MFF 2014-2020, EUROPEAN UNION, http://ec.europa.eu/budget/ mff/index2014-2020_en.cfm (last visited Feb. 13, 2019) (explaining how the MFF provides a seven-year budget for the EU to advance specified initiatives, but the allocation of the funds could vary over the course of the seven-year period due to built-in flexibility mechanisms). 
"producing safe and secure food supplies, innovative farming and efficient and sustainable use of land and forests." 77 Reducing this funding, which is designed to assist the welfare of disadvantaged populations, could have a significant impact on human rights, and so the European Union may not wish to utilize this type of economic sanctioning.

In Poland's case on July 26, 2017, the European Commission launched "an infringement proceeding against Poland for breaches of EU law."78 In its press release, the commission threatened to "trigger Article 7(1) procedure" and issued several recommendations for revisions to recent reform efforts due to concerns about the "lack of an independent and legitimate Constitutional review in Poland."79 Poland was given one month to address the European Commission's concerns about the commission's desire to "pursue a constructive dialogue with the Polish Government." 80 The press release made clear that if Poland did not make substantial progress towards compliance with EU standards of judicial independence, infringement proceedings would continue. ${ }^{81}$

Poland, however, did not change its course and instead solidified its alliance with Hungary, another country under attack by the European Union for its lack of adherence to the rule of law. ${ }^{82}$ On September 25, 2017, the President of Poland, Andrzej Duda, who previously vetoed several of the controversial judicial reform bills, called for "further 'consultations' over potential changes to the constitution." 83 Poland continued to waver in its commitment to maintaining judicial independence; the PiS majority political party disagreed with politicians like the president on what should be done in the face of potential EU sanctions. As a result, the European Commission again found that Poland had not made considerable progress and has since "moved to the next stage of the infringement procedure." 84 In this stage, the European

77. See Budget, supra note 75.

78. European Commission Press Release IP/17/2161, The European Commission Acts to Preserve the Rule of Law in Poland (July 26, 2017), http://europa.eu/rapid/pressrelease_IP-17-2161_en.htm.

79. Id.

80. Id.

81. Id.

82. Lili Bayer, Poland and Hungary Stand United (Except on Russia), PoLITICO (Sept. 23, 2017, 6:43 PM), http://www.politico.eu/article/poland-hungary-stand-united-except-onrussia-orban-szydlo/.

83. Polish President Urges Constitutional Change Amid Plans for Legal Reform, RADIO Poland (Sept. 25, 2017, 1:11 PM), http://www.thenews.pl/1/9/Artykul/327351,Polishpresident-urges-constitutional-change-amid-plans-for-legal-reform.

84. Hervey \& Livingston, supra note 65. 
Commission again issued a notice to Poland urging the state to take "appropriate measures" to address their concerns or the Commission would refer the case to the Court of Justice of the EU.85 Thereafter, the European Commission granted Poland another month to work towards correcting infringements on articles on the Treaty on the Functioning of the European Union (TFEU) and the Treaty on European Union (TEU). 86

The Polish government still did not comply with EU calls for compliance. On December 20, 2017, the European Commission elevated the infringement procedures as to the ordinary courts within Poland and stated that there was a "clear risk of a serious breach of the rule of law." 87 On June 27, 2018, the EU General Affairs Council held a hearing to consider the crisis in Poland. 88 The Polish government gave no indication "of forthcoming measures to address the Commission's outstanding concerns." 89 Furthermore, the crisis in Poland worsened on June 28, 2018, when the government executed a "sweeping purge of the Supreme Court" and forced retirement of twenty-seven justices, including the top judge. ${ }^{90}$ The European Commission again invoked infringement proceedings in line with Article 7(1) but this time regarding actions taken against the Supreme Court by issuing a Letter of Formal Notice on July 2, 2018. ${ }^{91}$ The European Commission gave Poland one month to reply to the formal notice. Unsurprisingly, at a follow up hearing with the General Affairs Council, the Polish government held steadfast to its position. ${ }^{92}$ On September 24, 2018, the commission referred Poland to the EU Court of Justice "due to its violation of the principle of judicial independence."93

The infringement proceedings remain ongoing without a foreseeable end in sight. Perhaps other enforcement methods of judicial independence standards would be more effective either independently or in conjunction with action taken by the European Union.

85. Id.

86. Id.

87. European Commission Press Release IP/17/3186, The Commission, Independence of the Judiciary: European Commission Takes Second Step in Infringement Procedure against Poland (Sept. 12, 2017), http://europa.eu/rapid/press-release_IP-17-3186_en.htm.

88. Id.

89. Id.

90. Marc Santora, Poland Purges Supreme Court, and Protesters Take to Streets, N.Y. TIMES (July 3, 2018), https://www.nytimes.com/2018/07/03/world/europe/poland-supremecourt-protest.html?module=inline.

91. European Commission Press Release IP/18/4341, The Commission, Rule of Law: Commission Launches Infringement Procedure to Protect the Independence of the Polish Supreme Court (July 2, 2018), http://europa.eu/rapid/press-release_IP-18-4341_en.htm.

92. Id.

93. Id. 


\section{The Role of Private Actors}

As previously discussed, economic factors play a strong role in encouraging judicial reform, and judicial independence plays a strong role in maintaining a healthy economy. As such, economic measures can effectively persuade governments to comply with international standards, especially considering the essential relationship between states and private actors such as international corporations. States rely on international commerce to bolster their economic health, while international businesses rely on state protection of judicial independence for their long-term prosperity, which is closely linked to the adjudication of their international disputes. ${ }^{94}$ Because private actors maintain a level of flexibility and freedom in their activities that intergovernmental organizations do not possess, they may be best positioned to engage in economic measures to enforce international standards of judicial independence.

Economic development does not occur without investments by businesses, many of which are international private actors. 95 These private actors will not invest unless they have confidence that they will turn a profit and that there is a low amount of risk. ${ }^{96}$ Thus, factors such as judicial independence can play a role in a private actor's decision to invest in a country's economy. ${ }^{97}$ This is because an independent judiciary is essential to maintaining private property rights and because private actors must rely on the judiciary to adjudicate their legal disputes-the outcome of which influences the health of their businesses. 98 Without judicial independence, private actors cannot be sure that "courts do not favor politically powerful or connected parties in contractual disputes" or that courts will not "always side with the government."99 Thus, private actors have a marked interest in ensuring that judicial independence is maintained in regions where they have made significant economic investments ${ }^{100}$ and are unlikely to invest in

94. See Phillips, supra note 7, at 929 ("Independent judiciaries] resolve commercial disputes in a predictable and transparent fashion that encourages fair competition and economic growth").

95. Klerman, supra note 7 , at 428 .

96. See id. (describing how "[i]n most developed countries, constitutional guarantees and powerful courts reduce the risk of expropriation," and so this would be an environment where investments would occur).

97. See generally Feld \& Voigt, supra note 32, at 516 (showing a positive link between the presence of judicial independence and gains in countries' overall GDP through a study of 57 countries).

98. Id.

99. Klerman, supra note 7 , at 428 .

100. Id. 
countries where judicial independence is threatened. 101

Recent scholarship has noted the importance of judicial independence in a country's economic health, which supports the notion that countries must evaluate economic risk when making decisions about judicial structure. ${ }^{102}$ Because private actors invest in countries where they can rely on judicial independence for the fair adjudication of their disputes, countries must maintain judicial independence for the betterment of their economy by private actors. ${ }^{103}$ Where one party fails to uphold their side of this relationship, both parties feel the economic consequences. ${ }^{104}$ Private actors thus have an incentive to encourage states to move toward compliance with international standards of judicial independence. 105

Private actors may advocate for judicial reform in a few ways. For example, on a basic level, a private actor may cause direct economic consequences by simply withdrawing its business from countries that do not maintain judicial independence. ${ }^{106}$ Whereas intergovernmental organizations like the European Union must carefully consider the impact of withdrawal of funds from member states, private actors maintain a higher level of freedom and can make decisions solely based on the health of their business. This impact on the promotion of the independent judiciary would be felt more significantly if private actors banded together and directly communicated a message of disapproval against countries that did not uphold standards of judicial independence. The counterpoint to this approach would be that

101. Id.

102. See, e.g., Shetreet, supra note 34, at 14; see also Phillips, supra note 7 , at 918 (discussing judicial reform and judicial independence as essential to the development of countries such as Poland); Klerman, supra note 7, at 434 (describing judicial independence as essential to the economic health of a country).

103. Klerman, supra note 7 , at 428 .

104. When judicial independence is absent, private investors are not likely to invest in the country's economy. Private actors that already have investments may suffer financial losses where judiciaries that adjudicate their disputes are not independent and impartial because the judiciary may by default hold in favor of the government or the interests of the dominant political party. The country, in turn, faces economic backlash when investors withdraw due to fears of lost profits and financial insecurity. See Klerman, supra note 7, at 428 (depicting the economic theory behind judicial independence's encouragement of investment by private actors and how countries must maintain judicial independence to avoid economic consequences).

105. See Phillips, supra note 7 , at 920 (explaining the role of private actors in shaping judicial reform through the expenditure of "loans, grants, and technical expertise, international organizations, donors, nongovernmental organizations, and private consultants").

106. See generally Stephan, supra note 18, at 1584-85 (describing the recent increase of upstream international lawmaking by private actors who utilize economic means as ways to shape the law in favor of effective global business transactions). 
attacking the economy of a country could eventually have an impact on the state of human rights through the loss of jobs and overall decrease in profit by the people living there. This impact on human rights, however, would perhaps be less extreme than if the European Union were to withdraw its funding that directly assists vulnerable comm unities whom are already at risk.

Private actors concerned about directly cutting ties with noncompliant countries could instead make investments into organizations, such as CEELI, that promote judicial independence in areas without a strong tradition of independent judiciaries. These positive investments may have a higher correlation in encouraging the protection of judicial independence as both send a direct message in support of judicial independence and support organizations actively working to promote it. There is a strong history of private actors effectively shaping the promulgation of the rule of law, especially in central and eastern Europe. ${ }^{107}$ This export of the rule of law to private entities is fairly harmless as long as it can be assured that these private actors do not inappropriately use these investments for their own gain (such as engaging in corruption or conduct such as bribery). ${ }^{108}$ If private actors contain their financial investments to NGOs that have proven to support judicial reform, this could be an effective way of promulgating adherence to judicial independence standards.

In the case of Poland, threats to judicial independence have already created concern that Poland would face future economic difficulty. In an interview with Bloomberg News in Brussels, Principal Vice President Frans Timmermans of the European Commission noted that the "attack on judicial independence has given foreign investors jitters about the credibility of the Polish legal system." 109 Timmermans asserted that the threat to judicial independence was "a business issue" and that investors would worry about the "security of [their] investments." 110 Thus, an opportunity exists for private actors to openly decry the Polish government's actions in limiting judicial independence. This open

107. See, e.g., Phillips, supra note 7, at 928 (discussing the promotion of judicial independence through Central and Eastern Europe, driven by the funding of private actors).

108. See id. at 932 (describing the pitfalls of private investment in judicial reform as the judiciary becoming beholden to private entities rather than political parties, but also discounting this theory as a shortcoming of the poor planning of the executed judicial independence reforms in question).

109. Jonathan Stearns, Ewa Krukowska \& Nikos Chrysoloras, Poland's Authoritarian Shift Spurs Warning of Economic Trouble, BLOOMBERG (Sept. 17, 2017), https://www.bloomberg.com/news/articles/2017-09-17/poland-s-authoritarian-shift-spurswarning-of-economic-trouble.

110. Id. 
condemnation of threats to judicial independence, especially when coupled with either economic threats or investments in NGOs dedicated to the promulgation of judicial independence, could be the influence Poland needs to return to compliance. While there are indications that pressure from the European Union may slowly convince Poland to change its course, immediate threats to the country's economy may cause quicker action (whereas action by the European Union could take several months due to the need for recommendations and court proceedings before the institution of sanctions).

\section{Creating a Model for the Effective Promotion of INTERNATIONAL STANDARDS OF JUDICIAL INDEPENDENCE}

As discussed, both intergovernmental and private actors recognize the importance of judicial independence. Therefore, the best model for the effective regulation of international standards of judicial independence in Europe would involve the cooperation by the European Union and private actors with economic interests in the region.

This model would involve the promulgation of concrete standards of judicial independence much like the Mount Scopus International Standards of Judicial Independence that have a larger focus on establishing organizational safeguards. These standards could contain provisions that state (but are of course not limited to) that the executive and legislature should not be allowed power to overturn judicial decisions, that compensation for judges should be adequate and fixed, and that judicial disciplinary committees must be independent bodies not subject to excessive oversight by the other branches of government. Importantly, new standards would focus equally on the underlying ideals that support the notion of judicial independence (such as the right to a fair trial) and on ways that countries can draft constitutions and formulate governmental structures that ensure judicial independence is protected.

With more well-defined and stricter international standards of judicial independence, it would be more difficult for EU member states to deviate from standards in the future. However, in the event of noncompliance, private actors who are not tied to the administrative bureaucracy of international government organizations could act as the enforcers of these standards by utilizing economic punishment and incentives. When countries deviate from standards of judicial independence as outlined by the European Union, private actors can band together to withdraw their business from offending countries. Private actors can also collectively organize, contribute to organizations that promote judicial independence, and publicly comment about their 
decision to avoid business in countries where judicial independence is threatened. This economic and social commentary, in combination with official efforts by the European Union, could add needed pressure to ensure that countries return to compliance. In this way, judicial independence could be better protected by recognizing the interests of both intergovernmental and private actors and ensuring the protection of both economic and human rights.

That said, the influence of private actors who are driven by economic interests works best when curbed by intergovernmental organizations who are more in tune with the needs of human rights initiatives. An effective model would avoid leaving too much discretion to private actors in the entirety of enforcement decisions as they may be persuaded to act with only their best economic interests in mind versus the public's need to have their rights secured.111 Primarily, the standards need to be drafted and shaped by the European Union, as their mission is to represent the needs of all people in Europe, not just corporations. With clear, unbiased objectives defined by the European Union, private actors would have clear guidelines of what constituted acceptable and unacceptable behavior on the part of EU member countries.

A balance must be struck to ensure the proper enforcement of standards of judicial independence without bias as to the country's economic standing or potential. For example, private actors may take into consideration the profitability of the market in question. Applying a cost-benefit analysis, a private actor could determine that potential unfair treatment in disputes in a country with low judicial independence is worth the risk due to the high potential for economic gain in the region and the monetary loss it would sustain by withdrawing its business. Moreover, it is possible that corruption could occur; private actors' economic threats could then make judiciaries too sympathetic when adjudicating private actors' disputes due to a pressure to retain their business in the country.

Thus, careful regulation by the European Union must occur to ensure that enforcement of standards of judicial independence is done fairly and equally among member states. The European Union could offer incentives for private actors to enforce judicial independence standards by enacting policy-perhaps conferring trade benefits for private actors that restrict their business to compliant member states. Thus, if the European Union were to adopt more specific and concrete

111. See Stephan, supra note 18, at 1619-23 (describing how law created for and by private actors leads to effective lawmaking for those parties, but that, in areas where human rights are involved, the cooperation of the state leads to more optimal results for all involved). 
standards of judicial independence, it could incentivize private actors to utilize them to identify and openly support countries where judicial independence is actively fostered while foregoing business where it is weak.

If a balance can be found, the needs of intergovernmental organizations, private actors with economic interests, and the people who reside in countries where judicial independence is at threat can all be met. With the combined influence of the European Union, who provides substantial benefit in terms of social welfare, and private actors, who provide support to the economy, non-compliant countries can be persuaded to return to compliance. In the absence of both the European Union and the investments of private actors, a country like Poland would surely suffer. So, by leveraging the influence of both parties in a combined effort, Poland may conform to EU values and ideals as proscribed by EU law.

\section{CONCLUSION}

With threats to the independence of Poland's judiciary, there is clearly a need for cooperation between the European Union and private actors with investments in the region. While the European Union can provide the necessary law, values, and structure to mandate that an independent judiciary be present in its member states, its enforcement proceedings for non-compliance can be lengthy and overly bureaucratic. Overall, non-compliant member states may not feel a sense of urgency when faced with threats of Article 7 procedures, especially absent a history of these sanctions ever being utilized. Private actors, on the other hand, are not tied down by diplomatic concerns and can act in line with their economic interests, which are greatly influenced by a lack of judicial independence. Private actors can have a significant impact on the promotion of judicial independence in a country like Poland by utilizing both economic threats and investments in NGOs that promulgate judicial independence. The weight of sanctioning by the European Union can effectively be combined with direct and more immediate economic consequences by private actors.

Judicial independence is a core value of proper governance and ensures that all parties, no matter their social status or political identity, receive due process and a fair day in court. Thus, it is in the interest of the European Union not only to create or adopt a more welldefined set of standards to ensure that judicial independence is protected internationally but also to encourage enforcement mechanisms that effectively encourage non-compliant member states to adhere with standards. With the careful oversight of intergovernmental 
bodies, private actors can effectively advocate for judicial reform that both meets their economic interests and the human rights needs of the European people. 